\title{
The Effect of Shaking, $\mathrm{CO}_{2}$ Concentration and Light Intensity on Biomass Growth of Green Microalgae Desmodesmus communis
}

\author{
Juris Vanags ${ }^{1}$, Liene Kunga ${ }^{2}$, Konstantīns Dubencovs ${ }^{2}$, Vytautas \\ Galvanauskas $^{2,3}$, Maija Balode ${ }^{4}$, Oskars Grīgs ${ }^{2}$ \\ ${ }^{1}$ Biotechnical Centre, JSC, Riga, Latvia \\ ${ }^{2}$ Institute of Wood Chemistry, Bioengineering laboratory, Riga, Latvia \\ ${ }^{3}$ Kaunas University of Technology, Department of Automation, Kaunas, Lithuania \\ ${ }^{4}$ Latvian Institute of Aquatic Ecology, Riga, Latvia \\ Corresponding author: \\ J. Vanags, Biotechnical Centre, JSC, Dzerbenes St 27, Biotehniskais centrs, JSC, LV-1006 Riga, Latvia \\ E-mail: btc@edi.lv
}

\begin{abstract}
There are many factors that can affect microalgae growth. In this research, four different groups of experiments were set up in order to determine the influence of different mixing conditions, $\mathrm{CO}_{2}$ concentration and light intensities on Desmodesmus communis growth. The range of $\mathrm{CO}_{2}$ concentration in the air- $\mathrm{CO}_{2}$ mixture was $0-16 \mathrm{v} / \mathrm{v} \%$, light intensities ranged between $100 \mu \mathrm{mol} \mathrm{m}^{-2} \mathrm{~s}^{-1}$ and $300 \mu \mathrm{mol} \mathrm{m}^{-2} \mathrm{~s}^{-1}$. The best biomass productivity and biomass yield of $0.54 \mathrm{~g} \mathrm{~d}^{-1}$ and $3.53 \mathrm{~g} \mathrm{l}^{-1}$ respectively were achieved when mixing was provided by using shaker as well as gas bubbling with air- $\mathrm{CO}_{2}$ mixture of $96: 4 \mathrm{v} / \mathrm{v} \%$ and light intensity of $300 \mu \mathrm{mol} \mathrm{m}^{-2} \mathrm{~s}^{-1}$.
\end{abstract}

Keywords: microalgae, mixing, $\mathrm{CO}_{2}$ concentration, light intensities, biomass growth.

\section{Introduction}

Microalgae are relatively easy to cultivate, they can grow using wastewater as well as clean water and can easy obtain nutrients (Makarevičienè et al., 2011; Samori et al., 2013; Sheenan et al., 1998). Using photosynthesis, microalgae can reproduce themselves and complete all growth stages in a short time (Sheenan et al., 1998). Because of variety of highvalue biological derivatives, they can produce a wide range of feedstock for biofuel production and also for many other applications, for example, microalgae are also used in cosmetics, pharmaceuticals, nutrition and food additives, aquaculture, and pollution prevention (Makarevičienė et al., 2011; Makarevičienè et al., 2012; Mata et al., 2010; Schenk et al., 2008).

Those algae cultures from which producing of high value products is possible are usually cultivated under sterile conditions with relatively well-defined external parameters. Specially built photobioreactors can provide such conditions (Scott et al., 2010). They allow cultivation of single-species microalgae culture for long term and have been successfully used for producing large quantities of microalgal biomass (Chisti, 2007). Photobioreactors can operate in batch, fed-batch and continuous mode. Batch culture is one of the most used, and it can be characterised as a closed system, in which the volume is limited and resources are finite - cell density continuously increases until one or more of the limiting factors ends (Barsanti and Gualtieri, 2006).

Nevertheless, algae cultivation has its own challenges as well. One of the most critical links in microalgae research and application is strain selection - a need to select and grow highly productive algal strains (Han et al., 2012; Rodolfi et al., 2009). Then the energy consumption follows. Closed photobioreactors need energy for mixing the culture suspension, water pumping, gas compressing for bubbling $\left(\mathrm{CO}_{2}\right.$ transfer), harvesting/dewatering the culture biomass, and they have much embodied energy in the materials of construction (Rodolfi et al., 2009; Scott et al., 2010). One more limitation for large-scale production is the availability of the 
sources of nutrients; often chemical or inorganic fertilizers are used to achieve appropriate growth rate of microalgae (Lam et al., 2013). Moreover, even though $\mathrm{CO}_{2}$ may be available as flue gases from power or chemical plants on industrial scale, the distribution of $\mathrm{CO}_{2}$ is problematic (Scott et al., 2010). Still in many cases, because of the benefits of algae cultivation, it is worth dealing with and overcoming these challenges.

Biomass production is remarkably affected by environmental factors (Fang et al., 2013). The ones that influence the growth the most are light intensity and light-dark cycle, temperature, and nutrients status - concentrations of carbon and nitrogen, pH (Fang et al., 2013; Li et al., 2011). It is reported that mixing and aeration are also very important (Ugwu et al., 2007). Good mixing improves biomass productivity by increasing the frequency of cell exposure to light and dark volumes of the reactor as well as by increasing mass transfer between the nutrients and cells (Kunjapur et al., 2010).

The aim of this research is to study the influence of different mixing conditions, $\mathrm{CO}_{2}$ concentration and light intensities on algae biomass productivity in order to design an appropriate photobioreactor. To do so it is necessary to clarify all the factors which influence the results of algal cultivation as well as the parameter control possibilities. The experiments were performed in shake flasks because that is one of the easiest ways to provide multi-parameter variation in parallel experiments. This is also shown in Samori et al. work (2013) where different sets of experiments for Desmodesmus communis cultivation were run in batch culture in order to determine the effect of medium composition, $\mathrm{CO}_{2}$-air mixture, and light intensity on algae growth.

In the experiments performed, the authors have also used $D$. communis that is unicellular freshwater green algae.

\section{Methods}

\section{$2.1 \quad$ Microorganism and culture medium}

A novel strain of green algae was isolated from fresh water samples collected from estuary zone of River Daugava (Riga, Latvia) in August 2008. This novel strain was identified as $D$. communis named as DCDA-3 (culture collection of Latvian Institute of Aquatic Ecology).

Each bottle contained $400 \mathrm{ml}$ culture medium of BG11, which consisted of $1.5 \mathrm{~g} \mathrm{l}^{-1} \mathrm{NaNO}_{3}, 0.04 \mathrm{~g} \mathrm{l}^{-1}$ $\mathrm{K}_{2} \mathrm{HPO}_{4}, \quad 0.075 \mathrm{~g} \mathrm{l}^{-1} \quad \mathrm{MgSO}_{4} \cdot 7 \mathrm{H}_{2} \mathrm{O}, \quad 0.006 \mathrm{~g} \mathrm{l}^{-1}$ $\mathrm{Fe}\left(\mathrm{NH}_{4}\right)_{3}\left(\mathrm{C}_{6} \mathrm{H}_{5} \mathrm{O}_{7}\right)_{2}, 0.001 \mathrm{~g} \mathrm{l}^{-1}$ EDTANa $_{2}, 0.006 \mathrm{~g} \mathrm{l}^{-1}$ citric acid, $0.02 \mathrm{~g} \mathrm{l}^{-1} \mathrm{Na}_{2} \mathrm{CO}_{3}, 0.036 \mathrm{~g} \mathrm{l}^{-1} \mathrm{CaCl}_{2} \cdot 2 \mathrm{H}_{2} \mathrm{O}$, $0.001 \mathrm{~g} \mathrm{l}^{-1}$ vitamin $\mathrm{B} 1$ and trace element solution $0.000040 \mathrm{~g} \mathrm{l}^{-1} \quad \mathrm{CoCl}_{2} 6 \mathrm{H}_{2} \mathrm{O}, \quad 0.00286 \mathrm{~g} \mathrm{l}^{-1} \quad \mathrm{H}_{3} \mathrm{BO}_{3}$, $0.00181 \mathrm{~g} \mathrm{l}^{-1} \quad \mathrm{MnCl}_{2} \cdot 4 \mathrm{H}_{2} \mathrm{O}, \quad 0.000222 \mathrm{~g} \mathrm{l}^{-1}$ $\mathrm{ZnSO}_{4} \cdot 7 \mathrm{H}_{2} \mathrm{O}, \quad 0.00004 \mathrm{~g} \mathrm{l}^{-1} \quad \mathrm{Na}_{2} \mathrm{MoO}_{4} \cdot 2 \mathrm{H}_{2} \mathrm{O}$, $0.000080 \mathrm{~g} \mathrm{l}^{-1} \quad \mathrm{CuSO}_{4} \cdot 5 \mathrm{H}_{2} \mathrm{O}$. All media was autoclaved for sterilization at $120{ }^{\circ} \mathrm{C}$ for $45 \mathrm{~min}$. The volume of the seed culture used was appropriately chosen to obtain OD of 0.5 for culture media.

\subsection{Experimental setup and cultivation conditions}

Four parallel groups of experiments were set up for D. communis cultivation under different growth conditions: 1. Cultivation with aeration under static condition; 2. Cultivation with shaking and aeration; 3 . Cultivation with shaking and different light intensities; 4. Cultivation with aeration, shaking and different light intensities. Schematic diagram of the experiments setup is shown in figure 1 .

D. communis were grown in $500 \mathrm{ml}$ DURAN ${ }^{\circledR}$ GLS $80^{\circledR}$ laboratory bottles (height $148 \mathrm{~mm}$, diameter $101 \mathrm{~mm}$ ) filled with $400 \mathrm{ml}$ of culture medium. Cultivation temperature $25 \pm 1^{\circ} \mathrm{C}$ was provided by inserting thermostat tubes into all bottles. Illumination provided by LED (the light/dark periods were 16/8 h), aerated by bubbling air- $\mathrm{CO}_{2}$ mixture (100:0, 99:1, 96:4, $92: 8$ and 84:16 v/v\%), which was continuously supplied with a flow rate of $0.5 \mathrm{vvm}$ (gas volume per liquid culture volume and per hour). The culture was stirred using BioSan PSU-20i multifunctional orbital shaker. For illumination, the cases were used that were made of $3 \mathrm{~m}$ long LED 3528 strips 9,6 W IP33 (white/cold), with 60 LEDs per meter. Light intensity for Group I and Group II in each bottle was $200 \mu \mathrm{mol} \mathrm{m} \mathrm{m}^{-2} \mathrm{~s}^{-1}$ but in the bottles from Group III and IV there were different light intensities: 100, 200, and $300 \mu \mathrm{mol} \mathrm{m} \mathrm{m}^{-2} \mathrm{~s}^{-1}$. The appropriate light intensity was adjusted using LED dimmer and measured by a Li250A Light Meter with a Li-190 quantum sensor (LiCOR Inc., Lincoln, Nebraska USA). All the experiments were performed in duplicates.

Experimental setup for each group:

I) Cultivation with aeration under static conditions: cultivation was performed in bottles equipped with a gas sparger and a reflux condenser.

II) Cultivation with shaking and aeration: shaker (160 rpm), bottles equipped with gas sparger and a reflux condenser.

III) Cultivation with shaking and different light intensities: shaker $(160 \mathrm{rpm})$, bottles.

IV) Cultivation with aeration, shaking and different light intensities: shaker $(160 \mathrm{rpm})$, bottles equipped with a gas sparger and a reflux condenser.

Table 1 shows summary of cultivation conditions for all experiments.

\subsection{Biomass production}

The culture was monitored by optical density measurement at a wavelength of $550 \mathrm{~nm}$ using a Jenway 6300 spectrophotometer after appropriate dilution. Cell dry weight (CDW, $\left.\mathrm{g} \mathrm{l}^{-1}\right)$ of $D$. communis could be correlated to the OD (optical density) at $550 \mathrm{~nm}$ with a linear equation (1):

$$
C D W=0.45 \times O D
$$


Biomass productivity was calculated from the variation in biomass concentration within a cultivation time using equation (2):

$$
P=\frac{\left[X_{1}-X_{0}\right]}{\left[t_{1}-t_{0}\right]}
$$

where $X_{0}$ is biomass concentration $\left(\mathrm{g} \mathrm{l}^{-1}\right)$ on day $\mathrm{t}_{0} ; X_{I}$ is biomass concentration $\left(\mathrm{g} \mathrm{l}^{-1}\right)$ on day $t_{l}$.

Table 1. Plan of growth conditions for all groups.

\begin{tabular}{|c|c|c|c|c|c|}
\hline Group & \begin{tabular}{|l|} 
Experiment No. \\
\end{tabular} & Light intensity, $\mu \mathrm{mol} \mathrm{m}^{-2} \mathrm{~s}^{-1}$ & Shaking, rpm & \begin{tabular}{|l|} 
Bubbling, $\mathrm{l} \mathrm{l}^{-1} \mathrm{~m}^{-1}$ \\
\end{tabular} & $\mathrm{CO}_{2}$ concentration, $\mathrm{v} / \mathrm{v} \%$ \\
\hline \multirow{2}{*}{ I } & 1 & 200 & - & 0.5 & 4 \\
\hline & 2 & 200 & - & 0.5 & 8 \\
\hline \multirow{5}{*}{ II } & 4 & 200 & 160 & 0.5 & 4 \\
\hline & 5 & 200 & 160 & 0.5 & 8 \\
\hline & 6 & 200 & 160 & 0.5 & 16 \\
\hline & 7 & 200 & 160 & 0.5 & 0 \\
\hline & 8 & 200 & 160 & 0.5 & 1 \\
\hline \multirow{3}{*}{ III } & 9 & 100 & 160 & - & - \\
\hline & 10 & 200 & 160 & - & - \\
\hline & 11 & 300 & 160 & - & - \\
\hline \multirow{3}{*}{ IV } & 12 & 100 & 160 & 0.5 & 4 \\
\hline & 13 & 200 & 160 & 0.5 & 4 \\
\hline & 14 & 300 & 160 & 0.5 & 4 \\
\hline
\end{tabular}

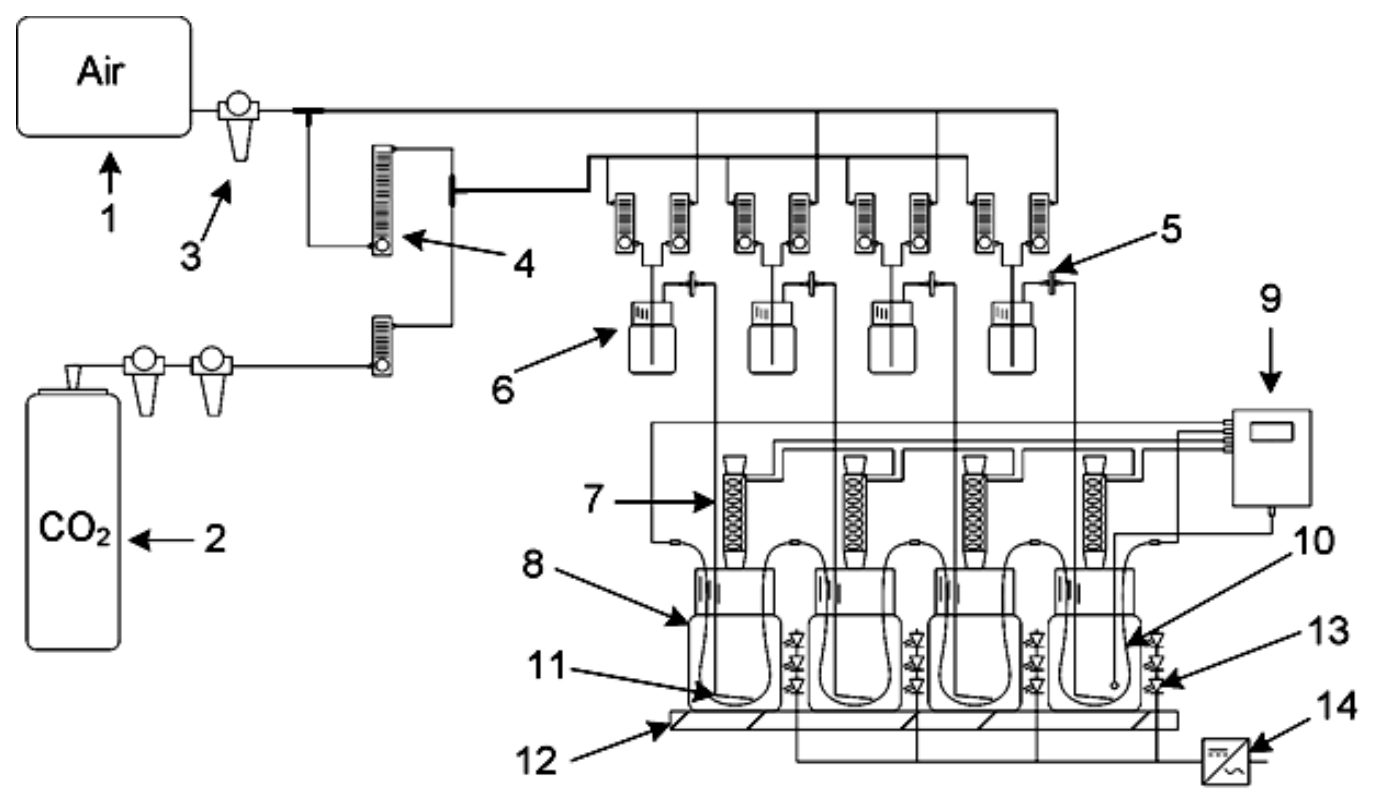

Figure 1. Schematic diagram of the experiment setup: 1 - air pump; 2 - $\mathrm{CO}_{2}$ cylinder; 3 - reductor; 4 - gas flow meters; 5 -filter; 6 - pure water; 7 -condenser; 8 - microalgae cultures; 9 -thermostat; 10 -thermostat tubes; 11 gas sparger; 12 - orbital shaker; 13 - LED; 14 -DC/AC adapter.

\section{Results and discussion}

In literature there is mentioned that mixing, light intensity and $\mathrm{CO}_{2}$ concentration are parameters that may essentially influence the growth of algae (Sforza et al., 2012). There are different ways how the culture cultivated in flasks can be mixed. For example, it can be mixed manually - hand shaken - one or more times a day (Makarevičienè et al., 2011), it can be mixed using a shaker (Han et al., 2012) and also by means of aeration (Barsanti and Gualtieri, 2006). Information in literature on optimal light intensity and $\mathrm{CO}_{2}$ concentration for successful microalgae growth differs (Fang et al., 2013; Samori et al., 2013; Soletto et al., 2008).

\subsection{Group I-Cultivation with aeration}

In order to determine the influence of mixing on microalgae growth, in Group I D. communis were cultivated without shaking but with aeration using two different $\mathrm{CO}_{2}$ concentrations -4 and $8 \mathrm{v} / \mathrm{v} \%$ (gas supply was $\left.0.511^{-1} \mathrm{~m}^{-1}\right)$. The effect of these $\mathrm{CO}_{2}$ concentrations on biomass growth is illustrated in Figure 2. As shown in Figure 2, the growth profiles of D. communis were very similar for $\mathrm{CO}_{2}$ concentrations of 4 and $8 \mathrm{v} / \mathrm{v} \%$. Maximal biomass productivity for $4 \% \mathrm{CO}_{2}$ was $0.47 \mathrm{~g} \mathrm{~d}^{-1}$, while for $8 \mathrm{v} / \mathrm{v} \% \mathrm{CO}_{2}$ the productivity was $0.43 \mathrm{~g} \mathrm{~d}^{-1}$. 


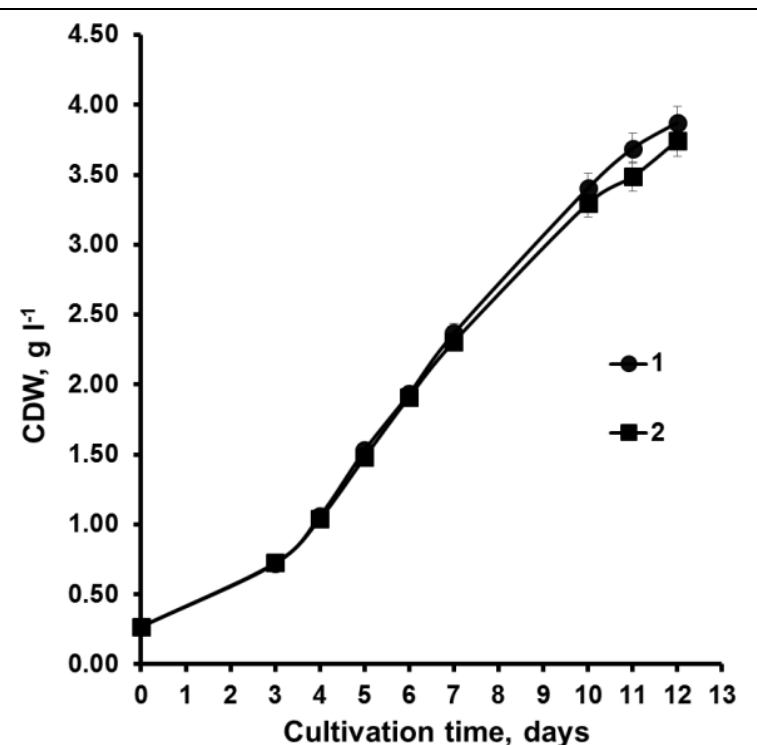

Figure 2. Effect of $4 \mathrm{v} / \mathrm{v} \% \mathrm{CO}_{2}(1)$ and $8 v / v \% \mathrm{CO}_{2}(2)$ on algae biomass growth when mixing provided only by gas bubbling.

On day 12 , the accumulated DCW was 3.9 $(4 \mathrm{v} / \mathrm{v} \%)$ and $3.7 \mathrm{~g} \mathrm{l}^{-1}(8 \mathrm{v} / \mathrm{v} \%)$ thus showing that even though measurements at both concentrations almost perfectly match each other, still it is $\mathrm{CO}_{2}$ concentration of $4 \mathrm{v} / \mathrm{v} \%$ that gives better results.

\subsection{Group II - Cultivation with aeration and shaking}

Unlike Group I, the experiments of Group II were performed using gas bubbling with three different $\mathrm{CO}_{2}$ concentrations $-4,8$, and $16 \mathrm{v} / \mathrm{v} \%-$ and a shaker, which was set up for $160 \mathrm{rpm}$ providing sufficient mixing. Figure 3 illustrates the effect of $\mathrm{CO}_{2}$ concentration on D. communis biomass growth.

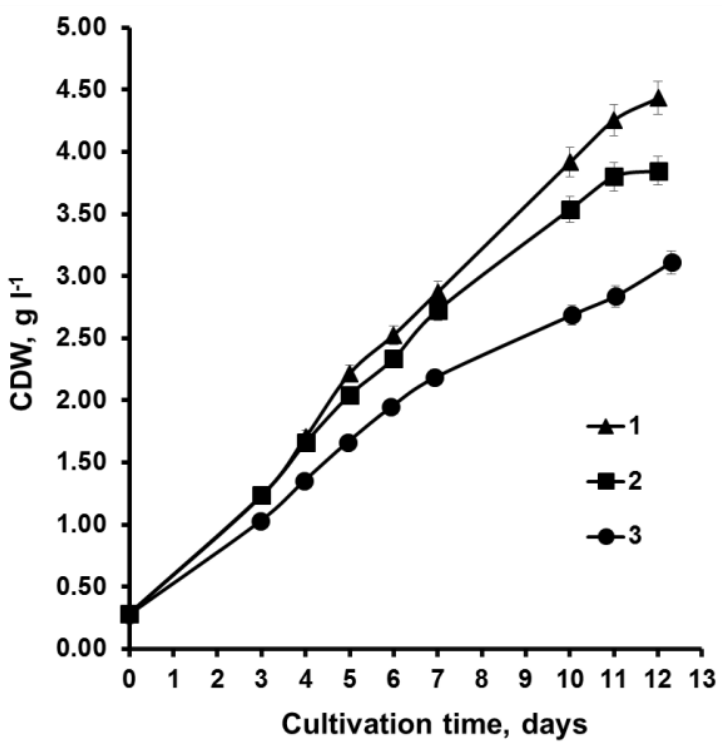

Figure 3. Effect of $4 v / v \%$ (1), $8 v / v \%$ (2) and $16 v / v \%$ (3) of $\mathrm{CO}_{2}$ on algae biomass growth when mixing provided by shaker and gas bubbling.

At the beginning of the experiment, there is no significant difference between results obtained using 4 and $8 \mathrm{v} / \mathrm{v} \%$ of $\mathrm{CO}_{2}$ concentration. The differences appear after day 4. Using $4 \mathrm{v} / \mathrm{v} \% \quad \mathrm{CO}_{2}$, maximal biomass productivity of $0.51 \mathrm{~g} \mathrm{~d}^{-1}$ was reached, but with $8 \mathrm{v} / \mathrm{v} \%$ it was $0.42 \mathrm{~g} \mathrm{~d}^{-1}$ and with $16 \mathrm{v} / \mathrm{v} \% \mathrm{CO}_{2}$ $0.32 \mathrm{~g} \mathrm{~d}^{-1}$. At the end of the experiment, the highest dry cell weight reached was $4.43 \mathrm{~g} \mathrm{l}^{-1}$ by using $4 \mathrm{v} / \mathrm{v} \%$ of $\mathrm{CO}_{2}$, while 8 and $16 \mathrm{v} / \mathrm{v} \%$ yielded in $3.85 \mathrm{~g} \mathrm{l}^{-1}$ and $3.2 \mathrm{~g} \mathrm{l}^{-1}$, respectively.

Furthermore, in the experiments performed at 8 and $16 \mathrm{v} / \mathrm{v} \% \mathrm{CO}_{2}$, the inhibition of culture growth was observed. It can be explained by low $\mathrm{pH}$ and osmotic stress. This inhibition shows that 8 and $16 \mathrm{v} / \mathrm{v} \%$ concentrations are too high for $D$. communis cultivation under given conditions.

Another set of experiments using 0, 1 and $4 \mathrm{v} / \mathrm{v} \%$ of $\mathrm{CO}_{2}$ were performed in order to examine the influence of lower $\mathrm{CO}_{2}$ concentration on algae biomass growth (Fig. 4).

As it is shown in Figure 4, the best biomass growth during the first 3 days was at low $\mathrm{CO}_{2}$ concentration ( 0 and $1 \mathrm{v} / \mathrm{v} \%$ ). After day 6 , the best growth was observed at $1 \mathrm{v} / \mathrm{v} \%$ but on day 10 at $4 \mathrm{v} / \mathrm{v} \%$. This could be explained by $\mathrm{CO}_{2}$ inhibition of culture growth at the beginning of the experiment, but later when the concentration of biomass increased, $\mathrm{CO}_{2}$ limitation changed the growth. On the last day of cultivation experiment where air without $\mathrm{CO}_{2}$ was used (day 13) the lowest results $\left(2.55 \mathrm{~g} \mathrm{l}^{-1}\right)$ yielded reaching maximal productivity of $0.43 \mathrm{~g} \mathrm{~d}^{-1}$.

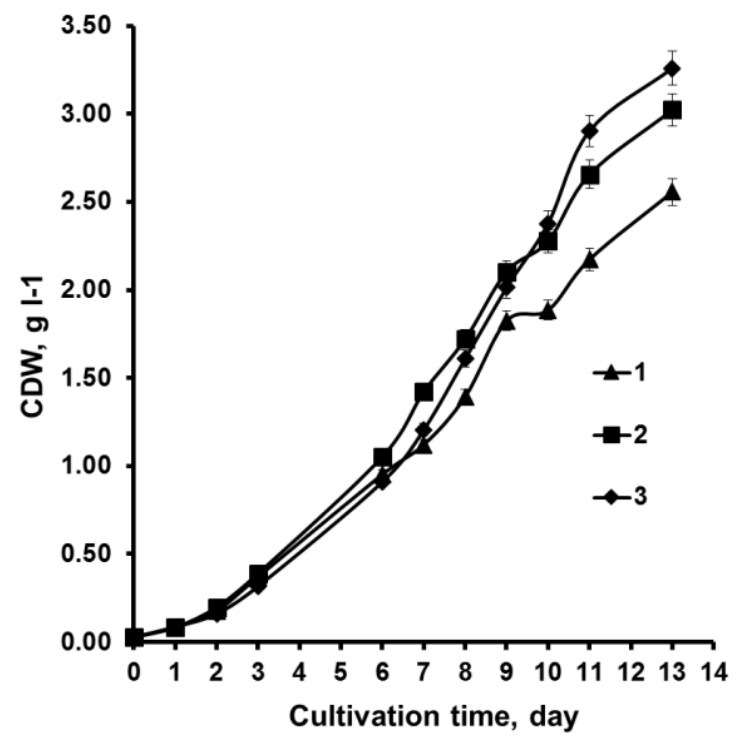

Figure 4. Effect of $0 v / v \%$ (1), $1 v / v \%$ (2) and $4 v / v \%$ (3) of $\mathrm{CO}_{2}$ on algae biomass growth when mixing provided by shaker and gas bubbling.

The highest biomass concentration $\left(3.26 \mathrm{~g} \mathrm{l}^{-1}\right)$ and productivity $\left(0.53 \mathrm{~g} \mathrm{~d}^{-1}\right)$ were achieved when aeration with $4 \mathrm{v} / \mathrm{v} \% \mathrm{CO}_{2}$ mixture with air was used. Thus pointing out that such a low concentration as 0 or $1 \mathrm{v} / \mathrm{v} \%$ of $\mathrm{CO}_{2}$ is not sufficient when cultivating microalgae.

By comparing Group I and II, one can conclude that the application of shaker in addition to gas sparger gives better biomass growth at the same air$\mathrm{CO}_{2}$ mixture. This might be because of better gas transfer from gas to liquid phase and also because good mixing prevents sedimentation of algae. 
Furthermore, in both groups the best biomass growth was obtained when $4 \mathrm{v} / \mathrm{v} \%$ of $\mathrm{CO}_{2}$ mixture with air was used for aeration.

\subsection{Group III - Cultivation with shaking and different light intensities}

To study the effect of mixing and light intensity on algae growth, another experiment was performed where D. communis was cultivated with shaking and at three different light intensities $(100,200$, and $300 \mu \mathrm{mol} \mathrm{m}^{-2} \mathrm{~s}^{-1}$ ) but without aeration. The effect of the mentioned parameters is shown in Figure 5.

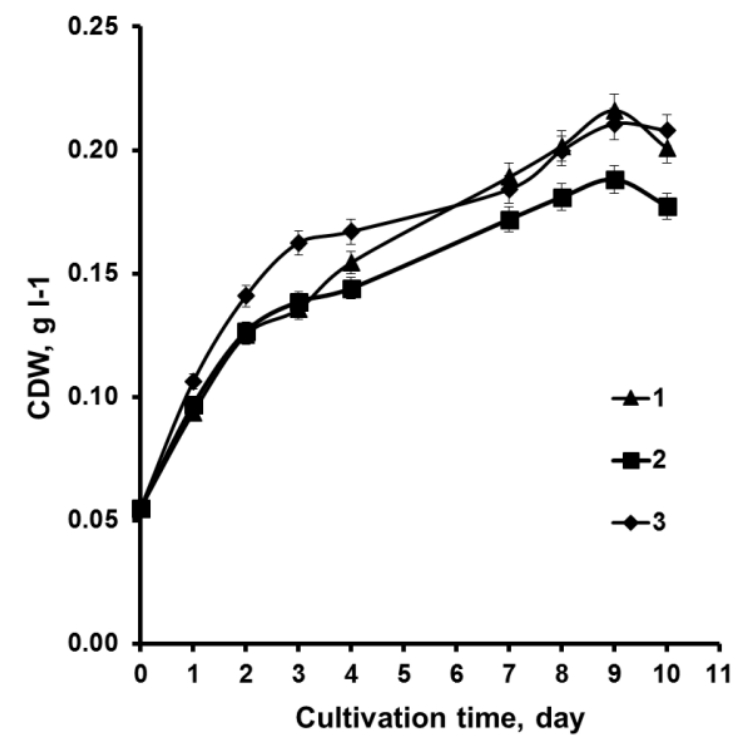

Figure 5. Effect of different light intensities $100 \mu \mathrm{mol} \mathrm{m} \mathrm{m}^{-1} \quad(1), 200 \mu \mathrm{mol} \mathrm{m} \mathrm{m}^{-2} \mathrm{~s}^{-1}$ (2) and $300 \mu \mathrm{mol} \mathrm{m} \mathrm{m}^{-2} \mathrm{~s}^{-1}(3)$ - on algae biomass growth when mixing was provided only by shaker.

Figure 5 shows that microalgae are growing very similar at all three given light intensities. The best productivity was determined at $100 \mu \mathrm{mol} \mathrm{m}^{-2} \mathrm{~s}^{-1}$ $0.05 \mathrm{~g} \mathrm{~d}^{-1}$. Maximal biomass yield was reached on day 9 at all light intensities but on the next day the cell lyses was observed in all bottles, which might occur due to biomass inhibition by oxygen.

Also, if one compares both experimental results of Group III with Group I and II (Fig. 2, 3 and 4), it is obvious that the results of Group I and II are better: they have higher productivity as well as maximal biomass yield, thereby showing that in order to increase biomass growth and final yield, algae cultivation should be done with aeration system enriched with $\mathrm{CO}_{2}$, just like Samori et al. stated in their article (2013).

\subsection{Group IV-Cultivation with aeration, shaking and different light intensities}

Just like in Group III, the experiments of Group IV were done to determine, which light intensity gives the best effect on algal growth, their difference - the experimental set up was supplemented with an aeration system: air- $\mathrm{CO}_{2}$ mixture of $4 \mathrm{v} / \mathrm{v} \%$.
In all bottles, the culture was supplied with air enriched with $\mathrm{CO}_{2}$ of $4 \mathrm{v} / \mathrm{v} \%$ (flow rate $0.511^{-1} \mathrm{~min}^{-1}$ ). Figure 6 illustrates the results obtained at such conditions.

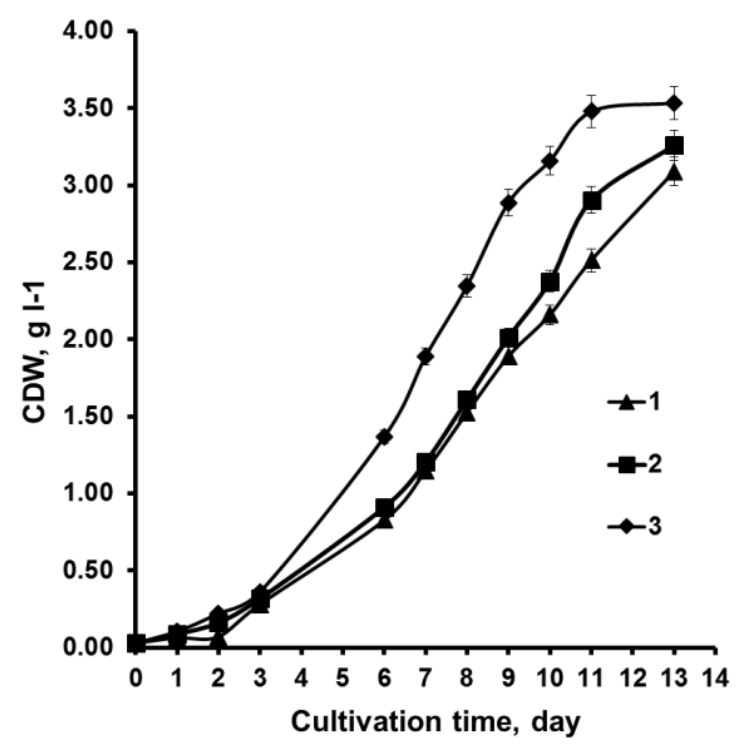

Figure 6. Effect of different light intensities $100 \mu \mathrm{mol} \mathrm{m} \mathrm{m}^{-2} \mathrm{~s}^{-1}$ (1), $200 \mu \mathrm{mol} \mathrm{m} \mathrm{m}^{-2} \mathrm{~s}^{-1}$ (2) and $300 \mu \mathrm{mol} \mathrm{m} \mathrm{m}^{-2} \mathrm{~s}^{-1}(3)$ - on algae biomass growth when mixing provided by shaker and gas bubbling $\left(4 \mathrm{v} / \mathrm{v} \%\right.$ of $\left.\mathrm{CO}_{2}\right)$.

As compared to the Group III, D. communis is growing significantly faster. Until day 3, light intensity had a small effect on algae biomass growth but after day 3 the highest biomass growth was obtained when light intensity was the highest of the three tested $-300 \mu \mathrm{mol} \mathrm{m}^{-2} \mathrm{~s}^{-1}$. The decrease in biomass productivity at lower light intensities might be due to the light shading effect arising from the increase in cell density (Chen et al., 2011). The maximal biomass productivity and biomass yield determined at $300 \mu \mathrm{mol} \mathrm{m}^{-2} \mathrm{~s}^{-1}$ was $0.54 \mathrm{~g} \mathrm{~d}^{-1}$ and $3.53 \mathrm{~g} \mathrm{l}^{-1}$, respectively.

\section{Conclusions}

In this research, unicellular microalgae D. communis was used to study the effect of different cultivation conditions on microalgae biomass growth. The results showed that for successful microalgae cultivation shaking and aeration is necessary. Variation of light intensity and concentration of $\mathrm{CO}_{2}$ can significantly affect biomass growth and yield. Best results (biomass productivity of $0.54 \mathrm{~g} \mathrm{~d}^{-1}$ and biomass concentration of $3.53 \mathrm{~g} \mathrm{l}^{-1}$ ) were obtained when mixing was provided by means of shaker and gas bubbling with $\mathrm{CO}_{2}\left(\right.$ air $\mathrm{CO}_{2}$ mixture $4 \mathrm{v} / \mathrm{v} \%$ ), at light intensity $300 \mu \mathrm{mol} \mathrm{m}^{-2} \mathrm{~s}^{-1}$.

\section{Acknowledgements}

The financial support from the ERAF within the scientific research project 'Research on high-quality 
product yield using microalgae cultivation in laboratory and pilot-scale bioreactors' (ref. No. 2013/0041/2DP/2.1.1.1.0/13/APIA/VIAA/025) is gratefully acknowledged.

\section{References}

Barsanti, L. and Gualtieri, P. (2006). Algae: anatomy, biochemistry, and biotechnology. Boca Raton, FL, USA: CRC Press.

Chen, C.Y., Yeh, K.L., Aisyah, R., Lee, D.J., Chang, J.S. (2011) Cultivation, photobioreactor design and harvesting of microalgae for biodiesel production: a critical review. Bioresource Technology 1(102): 71-81. doi: http://dx.doi.org/10.1016/j.biortech.2010.06.159.

Chisti, Y. (2007) Biodiesel from microalgae. Biotechnology Advances 3 (25): 294-306. doi: http://dx.doi.org/ 10.1016/j.biotechadv.2007.02.001.

Fang, J., Hao, R., Liu, Y., Li, G., Zhou, Y., Dong, R. (2013) Isolation of a novel microalgae strain Desmodesmus sp. and optimization of environmental factors for its biomass production. Bioresource technology 148: 249254 doi: http://dx.doi.org/10.1016/j.biortech. 2013.08.110

Han, W., Li, C., Miao, X., Yu, G. (2012) A novel miniature culture system to screen $\mathrm{CO} 2$-sequestering microalgae. Energies 11(5): 4372-4389. doi: http://dx.doi.org/ 10.3390/en5114372.

Hoshaw, R. W., Rosowski, J. R., Stein J. R. (1973). Handbook of phycological methods: Culture methods and growth measurements. Cambridge, UK: University Press

Kunjapur, A.M., Eldridge, R.B. (2010) Photobioreactor design for commercial biofuel production from microalgae. Industrial \& Engineering Chemistry Research 8(49): 3516-3526. doi: http://dx.doi.org/ 10.1021/ie901459u.

Lam, M.K., Lee, K.T. (2012) Potential of using organic fertilizer to cultivate Chlorella vulgaris for biodiesel production. Applied Energy 94: 303-308. doi: http://dx.doi.org/10.1016/j.apenergy.2012.01.075.

Li, Y., Zhou, W., Hu, B., Min, M., Chen P., Ruan, R.R. (2011) Integration of algae cultivation as biodiesel production feedstock with municipal wastewater treatment: strains screening and significance evaluation of environmental factors. Bioresource Technology 23(102): 10861-10867. doi: http://dx.doi.org/10.1016/ j.biortech.2011.09.064.

Makarevičienè, V., Andrulevičiūtė, V., Skorupskaitė V., Kasperovičienè, J. (2011) Cultivation of microalgae Chlorella sp. and Scenedesmus sp. as a potentional biofuel feedstock. Environmental Research, Engineering and Management 3(57): 21-27.

Makarevičienė, V., Skorupskaitè V., Andrulevičiūtè, V. (2012) Biomass and oil production of green microalgae Scenedesmu sp. using different nutrients and growth. Environmental Research, Engineering and Management 4(62): 5-13.

Mata, T.M., Martins, A.A., Caetano, N.S. (2010) Microalgae for biodiesel production and other applications: a review. Renewable and Sustainable Energy Reviews 1(14): 217-232. doi: http://dx.doi.org/10.1016/j.rser.2009.07.020.

Rodolfi, L., Zittelli, G.C., Bassi N.,Padovani, G., Biondi, N., Bonini, G., Tredicil, M.R. (2009) Microalgae for oil: Strain selection, induction of lipid synthesis and outdoor mass cultivation in a low-cost photobioreactor.
Biotechnology and Bioengineering 1(102): 100-112. doi: http://dx.doi.org/10.1002/bit.22033.

Samorì, G., Samori, C., Guerrini, F., Pistocchi, R. (2013) Growth and nitrogen removal capacity of Desmodesmus communis and of a natural microalgae consortium in a batch culture system in view of urban wastewater treatment: Part I. Water Research 2(47): 791-801. doi: http://dx.doi.org/10.1016/j.watres.2012.11.006.

Schenk, P.M., Thomas-Hall, S.R., Stephens, E., Marx, U.C., Mussgnug, J.H., Posten, C., Kruse, O., Hankamer, B. (2008) Second generation biofuels: high-efficiency microalgae for biodiesel production. Bioenergy Research 1(1): 20-43. doi: http://dx.doi.org/10.1007/ s12155-008-9008-8.

Scott, S.A., Davey, M.P., Dennis, J.S. Horst, I., Howe, C.J., Lea-Smith, D.J. (2010) Biodiesel from algae: challenges and prospects. Current Opinion in Biotechnology 3(21): 277-286. doi: http://dx.doi.org/10.1016/j.copbio. 2010.03.005.

Sforza, E., Simionato, D., Giacometti, G.M., Bertucco, A., Morosinotto, T. (2012) Adjusted light and dark cycles can optimize photosynthetic efficiency in algae growing in photobioreactors. PLoS ONE 6(7): e38975. doi: http://dx.doi.org/10.1371/journal.pone.0038975.

Sheehan J, Dunahay T, Benemann J, Roessler P. (1998). A look back at the U.S. Department of Energy's Aquatic Species Program - biodiesel from algae. Golden: National Renewable Energy Laboratory. doi: http://dx.doi.org/10.2172/15003040.

Soletto, D., Binaghi, L., Ferrari, L., Lodi, A., Carvalho, J.C.M., Zilli, M., Converti, (2008) A. Effects of carbon dioxide feeding rate and light intensity on the fed-batch pulse-feeding cultivation of Spirulinaplatensis in helical photobioreactor. Biochemical Engineering Journal 2(39): 369-375. doi: http://dx.doi.org/10.1016/j.bej. 2007.10.007.

Ugwu, C.U., Aoyagi, H., Uchiyama, H. (2008) Photobioreactors for mass cultivation of algae. Bioresource Technology 10(99): 4021-4028. doi: http://dx.doi.org/10.1016/j.biortech.2007.01.046. 


\title{
Purtymo, $\mathrm{CO}_{2}$ koncentracijos ir šviesos intensyvumo ịtaka žaliojo dumblio Desmodesmus communis biomasės augimui
}

\author{
Juris Vanags ${ }^{1}$, Liene Kunga ${ }^{2}$, Konstantīns Dubencovs ${ }^{2}$, Vytautas \\ Galvanauskas $^{2,3}$, Maija Balode ${ }^{4}$, Oskars Grīgs ${ }^{2}$ \\ ${ }^{1}$ Biotechnikos centras AS, Ryga, Latvija \\ ${ }^{2}$ Medienos chemijos institutas, Bioinžinerijos laboratorija, Ryga, Latvija \\ ${ }^{3}$ Kauno technologijos universitetas, Elektros ir elektronikos fakultetas, Automatikos katedra, Kaunas, Lietuva \\ ${ }^{4}$ Latvijos vandens ekologijos institutas, Ryga, Latvija
}

\begin{abstract}
Dumblių augimą gali lemti daugelis veiksnių. Šiame tyrime buvo atlikti keturių skirtingų grupių eksperimentai, kuriais buvo siekiama nustatyti skirtingų maišymo sąlygų, $\mathrm{CO}_{2}$ koncentracijos ir šviesos intensyvumo įtaką Desmodesmus communis augimui. $\mathrm{CO}_{2}$ koncentracijos ribos oro- $\mathrm{CO}_{2}$ mišinyje buvo $0-16 \mathrm{v} / \mathrm{v} \%$, šviesos intensyvumo ribos $100-300 \mu \mathrm{mol} \mathrm{m}^{-2} \mathrm{~s}^{-1}$. Nustatyta, kad didžiausias biomasès augimo greitis ir išeiga - atitinkamai $0.54 \mathrm{~g} \mathrm{~d}^{-1}$ ir $3.53 \mathrm{~g} \mathrm{l}^{-1}-$ buvo gauti, kai maišymas buvo atliekamas purtytuvu, tiekiant $96: 4 \mathrm{v} / \mathrm{v} \%$ oro- $\mathrm{CO}_{2}$ mišini ir esant $300 \mu \mathrm{mol} \mathrm{m} \mathrm{s}^{-2}$ šviesos intensyvumui.

Raktiniai žodžiai: dumbliai, maišymas, $\mathrm{CO}_{2}$ koncentracija, šviesos intensyvumas, biomasès augimas.
\end{abstract}

